\title{
Vital (Johannine) Signs: 'Crip-tic' Enactments of a Man at the Pool (John 5:1-18)
}

\author{
Louise J. Lawrence
}

It is now over two decades since David Mitchell and Sharon Snyder filmed and produced their video documentary Vital Signs: Crip Culture Talks Back (1995), which is largely comprised of footage from a conference on disability and the performing arts held at the University of Michigan entitled This/Ability. ${ }^{1}$ Viewers variously encounter Eli Claire's poetry on cerebral palsy-'I practised the sounds "th" "sh" "sl" for years / a pianist playing endless hours of scales / I had to learn the muscle of my tongue'; Carrie Sandahl, dressed in white scrubs covered in red writing (as if etched in blood) cataloguing scars, medical notes and insensitive questions her body has oft-times prompted in others; and Mary Duffy's naked representation of Venus de Milo, at once echoing 'the highest echelons of Western Art and culture' whilst provocatively questioning 'the reduction of her body to "congenital malformation"'. 2 These strong, intense and arresting performances are critically interspersed with historical activist footage including the Capitol Hill Crawl (1990), where hundreds left wheelchairs and crutches behind to physically pull themselves up steps to lobby for the Americans with Disability Act, and jarring scenes from mainstream Hollywood films including a young Shirley Temple insensitively goading a wheel-chaired companion that she 'could walk if [she] wanted to enough'. ${ }^{3}$

Vital Signs stands as a canonical piece of 'crip' culture, a 'visceral rewriting of the way that we understand disability' ${ }^{4}$ subversively unpicking what society at large has deemed 'normal' in regards to human bodies and seeking to give voice to the lived experiences of disability. Crip, like queer, once a deviant label-cripple-imposed by others is, in crip culture, subversively reappropriated as a charged, unsettling and strategic marginal position: intentionally challenging both a 'medical' model of disability (which views disability as a functional or biological defect in a body which needs diagnosis and treatment) ) $^{5}$ and a 'social' model of disability (which views the environment and social context bodies occupy as disabling). As Alison Kafer has recently stated, 'the harshness [of 'crip'] is a large part of the appeal . . . to jolt people out of their everyday understandings of body and mind, of normalcy and deviance . . "crip" and "cripple" are, in Eli Clare's formulation, "words to help forge a politics"'. 6

\footnotetext{
${ }^{1}$ David Mitchell and Sharon Snyder, 'Talking About Talking Back: Afterthoughts on the Making of the Disability Documentary Vital Signs: Crip Culture Talks Back', Michigan Quarterly Review 37, 2 (1988) 316-36. Available online at http://quod.lib.umich.edu/cgi/t/text/text$\mathrm{idx}$ ?cc=mqr;c=mqr;c=mqrarchive;idno=act2080.0037.216;rgn=main;view=text; $x c=1 ; g=$ mqrg [accessed 10/01/16].

2 Robert McRuer, Crip Theory: Cultural Signs of Queerness and Disability (New York University Press, 2006$), 51$.

${ }^{3}$ David Mitchell and Sharon Snyder, Vital Signs: Crip Culture Talks Back, Part 1. Available online at https://www.youtube.com/watch?v=r5rWHAOKcFc [accessed 10/01/16]. Some have since criticised the piece for 'its absence of non-white individuals. Given the absence of people of color, I suggest that a significant number of myths and misconceptions about who/what is constitutive of disability or "crip culture" are bolstered and reinforced in the film.' Chris Bell, 'Introducing white disability studies: a modest proposal', in Lennard Davis (ed.), The Disability Studies Reader (New York: Routledge, 2006), 275-82 (275). It could also be noted that Vital Signs exhibited physical disabilities to the neglect of mental or sensory conditions. These critiques are valid and important, though do not, I think, ultimately take away from the film's explosive and radical nature in its time (the 1990s).

${ }^{4}$ David Mitchell and Sharon Snyder, Cultural Locations of Disability (Chicago, IL: University of Chicago Press, 2005), 178.

${ }^{5}$ Christopher Newell, 'Disabled Theologies and the Journeys of Liberation to Where Our Names Appear', Feminist Theology 15, 3 (2007), 322-45 (324).

${ }^{6}$ Alison Kafer, Feminist, Queer, Crip (Bloomington: Indiana University Press, 2013), 15.
} 
In a very different context and time, the author of the fourth gospel likewise documented a series of his own (vital?) signs ${ }^{7}$ which variously featured ill and disabled bodies. ${ }^{8}$ The majority of scholarship has read these signs as miraculous 'facilitators of belief' ${ }^{\prime}$ through which 'people may begin to understand Jesus' identity and recognize his glory'. ${ }^{10}$ Social-scientific studies, however, have exposed how an over-emphasis on Christological intent alone can elide important cultural/communal functions that these signs, and their characters, play parts in constructing. ${ }^{11} \mathrm{~J}$. Louis Martyn's famed two-level reading of the fourth gospel, for example, saw the sign of the blind man in John 9 referring not just to a man healed by Jesus on the narrative level, but also representative on the historical level of the context of the Johannine community's expulsion from the synagogue in the late first century. ${ }^{12}$ More recently, Philip Esler and Ronald Piper have utilized social-identity theory to re-imagine the sign of Lazarus in John 11 as 'prototypical' and 'exemplary of the identity of a group ${ }^{13}$ in particular, including kinship patterns for house-based churches and the resolving of anxieties surrounding physical death within those communities. Warren Carter, utilizing a postcolonial lens, renders the disabled bodies within the signs as loci of a body politics. In his words, 'these bodies reveal the lie of imperial claims to be a force for wholeness and healing even while they compete with and imitate this imperial vision. John constructs an alternative world that participates in, imitates and contests Roman power. ${ }^{14}$

\footnotetext{
${ }^{7}$ The signs are usually listed as: the changing of water into wine (2:1-11); the healing of an official's son (4:46$54)$; the healing of the man at the pool (5:1-15); the feeding of the multitude (6:1-15); the healing of a man born blind (ch. 9); and the raising of Lazarus (ch. 11). For further discussion- see W. D. Davies, 'The Johannine "signs" of Jesus,' in Michael Taylor (ed.), A Companion to John: Readings in Johannine Theology (New York: Alba, 1977), 91-115; Robert T. Fortna, The Gospel of Signs: A Reconstruction of the Narrative Source Underlying the Fourth Gospel (SNTSMS 11; Cambridge University Press, 1970); Marianne Meye Thompson, 'Signs and Faith in the Fourth Gospel', Bulletin for Biblical Research 1 (1991), 89-108. Andreas Köstenberger has recently argued for the action in the temple being considered as not only as an additional, but also a uniquely authentic sign. He concludes: 'It appears that the temple cleansing, and it alone, meets all the criteria for inclusion in the Johannine signs. It is a work performed by Jesus as part of his public ministry, it is identified as a "sign" in the Fourth Gospel, and it symbolically points to God's glory displayed in Jesus, thus revealing Jesus as God's true representative. Jesus' crucifixion and resurrection, on the other hand, should not be considered as signs, since they relate to the seven signs featured in chaps. 1-12 as does reality to symbol.' Andreas Köstenberger, 'The Seventh Johannine Sign: A Study in John's Christology', Bulletin for Biblical Research 5 (1995), 87-103 (103).

${ }^{8}$ Though of course the ancient world would not use this 'disability' language, and one must be aware of the complexities and challenges of utilising contemporary models in relation to ancient and alien contexts.

${ }^{9}$ Paul Anderson, The Christology of the Fourth Gospel: Its Unity and Disunity in the Light of John 6 (WUNT 2/78, Tübingen: Mohr Siebeck, 1996), 268.

10 Jason Sturdevant, The Adaptable Jesus of the Fourth Gospel: The Pedagogy of the Logos (Leiden: Brill, 2015), 81. Thompson described a sign as 'a manifestation, through the person of Jesus, of God's work in the world'. See Thompson, 'Signs', 93-4.

${ }^{11}$ Wayne Meeks in his classic essay submitted that 'the man from heaven in Johannine sectarianism' embodies 'defines and vindicates the existence of the community that evidently sees itself as unique, alien from the world, under attack, misunderstood.' Wayne Meeks, 'The Man from Heaven in Johannine Sectarianism', Journal of Biblical Literature 91 (1972), 44-72.

12 J. Louis Martyn, History and Theology in the Fourth Gospel ( $3^{\text {rd }}$ ed.; Louisville, KY: Westminster John Knox, 2003). Note however Edward Klink's sustained critiques of this proposal, particularly his criticism of Martyn's

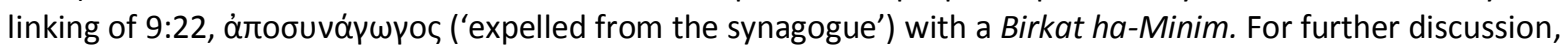
see Edward Klink, 'Expulsion from the Synagogue: Rethinking a Johannine Anachronism', Tyndale Bulletin 59, 1 (2008), 99-108.

${ }^{13}$ Philip Esler and Ronald Piper, Lazarus, Mary and Martha: Social-Scientific Approaches to the Gospel of John (Minneapolis, MN: Fortress, 2006), 17.

${ }^{14}$ Warren Carter, "'The Blind, Lame and Paralyzed” (John 5:3): John's Gospel, Disability Studies and Postcolonial Perspectives', in Candida Moss and Jeremy Schipper (eds), Disability Studies and Biblical Literature (New York: Palgrave Macmillan, 2011), 129-50 (130).
} 
With very 'few exceptions', however, the man at the pool has been understood in 'primarily negative terms' and as representative, if anything, of rivals to Johannine social identity. ${ }^{15} \mathrm{His}$ story, as is often pointed out, marks a change within the gospel from a largely positive reception of Jesus in the first four chapters, to increasing confrontation beginning here in chapter 5 . This sign is often seen to disclose three main themes: the power of Jesus' authority, Sabbath controversies and rising hostility from opponents. ${ }^{16}$ As such, this character poses, in the words of one recent commentator, 'a stark contrast to the very lovable man who was born blind. ${ }^{.17}$

Whilst recognizing the various roles (both positive and negative) that signs and their respective characters could potentially play in communal identity formation within the gospel, interpretations such as these still ultimately approach the signs 'cryptically' as socially-constructed 'riddles' to be deciphered, representative of something external to them. The disabled characters are thus understood (as is often the case in world literatures) as 'narrative prosthetics', ${ }^{18}$ metaphorical carriers of wider themes, and as such are 'screened out' and exiled in biblical studies, hidden 'behind other supposedly more important spiritual-theological realities'. ${ }^{19}$

In addressing this oversight, here I intend to read 'crip-tically' (through a crip hermeneutic), ${ }^{20}$ paying due attention to the man at the pool and his 'enactments'-a term drawn from Eliza Chandler to underline the fact that 'the meaning of disability is never static; from moment to moment, from interaction to interaction, from space to space, disability is enacted, and is enacted to mean differently ${ }^{21}$ - but also to see how his story has the potential subversively to refigure 'normative' understandings of time, space and embodiment within the gospel. This specific interest critically reflects so-called spatial and temporal turns (mobilized in critical geography and allied disciplines) whereby time and space are no longer conceived of as mere 'backdrop[s], container[s] or stage[s] to [and of] human life' but rather 'complex social formation[s], part[s] of a dynamic process'. ${ }^{22}$ Time and space are recognized as socially-constructed indices which frequently rely heavily upon 'metaphor and imagination' ${ }^{23}$ in their formation and maintenance. Through them, societies and communities are enabled to make sense of, and order, experiences.

John's gospel has of course long been seen to index time and space in intentional ways to construct worlds and identities. ${ }^{24}$ John's geography has been interpreted as highly symbolic: 'Jerusalem and Galilee are symbols respectively of rejection and acceptance. ${ }^{25}$ Others have emphasized the marked (and co-existent) binary landscapes of the narrative: 'above and below',

\footnotetext{
${ }^{15}$ John C. Thomas, "Stop Sinning Lest Something Worse Come Upon You": The Man at the Pool in John 5', Journal for the Study of the New Testament 59 (1995), 3-20 (3).

${ }^{16}$ Carter, 'The Blind', 130.

${ }^{17}$ Michael Card, John: The Gospel of Wisdom (Downers Grove, IL: InterVarsity Press, 2014), 76.

18 'Narrative prosthesis' is a term coined by David Mitchell and Sharon Snyder to denote the persistent use of disability as a device of characterization (often negative) in literature, film and other media. See their book of the same name: David Mitchell and Sharon Snyder, Narrative Prosthesis: Disability and the Dependencies of Discourse (Ann Arbor: University of Michigan Press, 2000).

${ }^{19}$ Carter, 'The Blind', 130.

${ }^{20}$ This has some affinities to the project I initiated in my book on sensory disability. See Louise J. Lawrence, Sense and Stigma in the Gospels: Depictions of Sensory-Disabled Characters (Oxford University Press, 2013).

${ }^{21}$ Eliza Chandler, Disability and the Desire for Community, Ph.D. thesis, University of Toronto (2014), 34. Available online at https://tspace.library.utoronto.ca/.../Chandler Eliza 201411 PhD thesis.pdf [accessed 10/01/16].

22 Edward Ayres, 'Turning Toward s Place, Space and Time' in David J. Bodenhamer, John Corrigan and Trevor M. Harris (eds), The Spatial Humanities: GIS and the Future of Humanities Scholarship (Bloomington: Indiana University Press, 2010), 1-13 (1).

${ }^{23}$ Sallie Westwood, Power and the Social (London: Routledge, 2002), 91.

${ }^{24}$ See Kenneth Mtata, Space and Place in the Gospel of John (Pietermaritzburg: University of KwaZulu-Natal, 2009).

${ }^{25}$ Thomas Brodie, The Gospel According to John: A Literary and Theological Commentary (Oxford University Press, 1998), 29. See also Jerome Neyrey, The Gospel of John in Cultural and Rhetorical Perspective (Grand Rapids, MI: Eerdmans, 2009), 81.
} 
'heaven and earth', 'ascent and descent', which play a part in narrating the community's own 'dislocated' identity, also, the symbolic 'lifting up' of the Word on the cross and 'the hour' marking the point of Jesus' death. The 'fixed' temple is for John, it is argued, 'declassified' and indexed anew in Jesus' body, a place where believers spatially 'indwell'. ${ }^{26}$ Construction of time has also loomed large in analyses of the gospel's eschatology: 'Combination[s] of both the realized and the final eschatology. Present and future elements' ${ }^{27}$ have dominated debates. A re-imagining of time and space have perhaps most consistently been referenced in interpretations of the cosmology of the gospel where the Word is presented as pre-existent and eternal; and as such, as Gail O'Day and Susan Hylen submit, 'move[s] readers outside of their own time frame and the created universe' and places them 'instead in the presence of God that transcends both time and space'. ${ }^{28}$

Productions of spatio-temporal frameworks inevitably pattern constructions of 'normative' bodies within cultures. Susan Wendell, for example, reveals how time is structured on 'normal' bodies, whether in regard to participation in activities or broader life courses in which futures are mapped. ${ }^{29}$ They also simultaneously dictate the exclusion, marginalization and stigmatizing of those 'other' bodies, which are perceived to transgress certain structures. As Elizabeth Teather notes: 'The social construction of disabling differences as markers of inferiority or otherness have, at both macro and micro scales, helped to situate disabled bodies as "out of place" in society and in the spaces of everyday life. ${ }^{30}$

The man at the pool, as will be seen, is 'othered'-'mark[ed] and name[d] as different', ${ }^{31}$ excluded, or deviant-by such indicators. He is understood to be isolated, segregated and marked by his solitude-'one man was there' (v. 5). His prolonged inactive state, 38 years (v. 5), is assumed to further underscore 'a lifetime of hopelessness' and $\sin ^{32}$ and 'reinforces his marginalized, deathlike state'. ${ }^{33}$ Negative understandings of disability and associated assumptions that such characters are inevitably 'out of time' and 'out of place' marked by victimhood, deviance, disorder and sin are all too common in interpretations.

In order to subvert notions of what Alison Kafer has termed 'curative time'-'an understanding of disability that not only expects and assumes intervention but also cannot imagine or comprehend anything other than intervention' ${ }^{34}-$ I will here purposively read the sign of the man at the pool as affording something other than a normalization or physical healing of his body. I will draw inspiration from two exhibits-Liz Crow's Bedding Out (2012-13) and Noëmi Lakmaier's One

\footnotetext{
${ }^{26}$ Neyrey, Gospel, 82.

27 Johannes Nissen, The Gospel of John and the Religious Quest: Historical and Contemporary Perspectives (Eugene: Wipf and Stock/ Pickwick Publications, 2013), 18.

${ }^{28}$ Gail O'Day, Susan Hylen, John (Louisville, KY: Westminster John Knox Press, 2006), 21.

${ }^{29}$ Licia Carlson, 'Music, intellectual disability, and human flourishing', in Blake Howe, Stephanie JensenMoulton, Joseph Nathan Straus and Neil Lerner (eds), The Oxford Handbook of Music and Disability Studies (Oxford University Press, 2016), 37-53 (39-40).

${ }^{30}$ Elizabeth Kenworthy Teather, Embodied Geographies (London: Routledge 1999), 151. See also debates in queer/crip theory surrounding futurity and its utility as a foundation for social action. On one end of the spectrum is Lee Edelman, who, as the title of his book suggests, No Future: Queer Theory and the Death Drive (Duke University Press, 2005), is suspicious of appeals to a 'reproductive futurism' and the inaction and passive acceptance of the status quo that this could promote. At the other end of the scale is José Esteban Muñoz, whose work, Cruising Utopia: The Then and There of Queer Futurity (New York University Press, 2009) is more eschatological in seeing queer time as a 'future bound phenomenon', 'a "not yet here" that critically engages pragmatic presentism'. Kafer, though sympathetic to Edelman's reservations, in the end veers more towards Muñoz's position in attributing a necessary futurity to crip time in its 'cultivation of disability' (Kafer, Feminist, 27).

${ }^{31}$ Weiss cited in Ajay Bailey, Culture, Risk and HIV/AIDS Among Migrant and Mobile Men in Goa, India (Amsterdam: Rozenberg, 2008), 189.

32 James L. Resseguie, The Strange Gospel: Narrative Design and Point of View in John (Leiden: Brill, 2001$), 136$.

${ }^{33}$ Resseguie, Strange, 135.

${ }^{34}$ Kafer, Feminist, 27. Original emphasis.
} 
Morning in May (2012) - both featured in Amanda Cachia's exhibition 'Performing Crip Time: Bodies in Deliberate Motion', held in the summer of 2014 in San Diego. ${ }^{35}$ This exhibition fronted artists ${ }^{36}$ who, through a variety of media-video, installation, dance, etc. - sought to probe 'how a disability perspective [might] bring new understandings of temporality through mobility across various public spaces' ${ }^{37}$ In the words of the curator, the exhibits demonstrated 'how we come to understand crip time, not as slower speed of movement, but also a re-orientation of time and bodies that might offer a new methodology for thinking about alternative futures for the disabled subject'. ${ }^{38}$

Whilst the sign of the man at the pool may not at first sight seem to hold much potential for crip-tic enactments of this sort, and whilst this reading will involve a certain reading against the grain of the text as a 'straight' miracle/healing story, one should at least be open to the potential of hermeneutical experiments such as these. For, as Chandler relates: 'However fleeting a story may be does not make it unimportant; perhaps importance lies in the act of its telling. Much like stories that shape bodies and space differently, community, too, is fleeting. Community slips, even sometimes at the moment that we think we have a hold on it . . we can never know crip community in totalitywhere it is, when it is, or with whom it will be enacted-for it will never totally 'be"'. ${ }^{39}$

One final disclaimer: I am an able-bodied academic (although hopefully not an 'ableist' one-discriminatory or prejudiced against bodily differences). In previous work, I have made the case that in biblical studies we are dealing with ancient and alien cultural evidence which does not offer details about the experiences or voices of those it deems 'disabled'. That is not to say, however, that what Mark Osteen terms 'an empathetic scholarship' 40 is a theoretical impossibility. The purposeful juxtaposition of contemporary crip culture with ancient performances, although inevitably anachronistic, also provides a useful stimulant for thinking differently in regard to disability. As I have argued elsewhere:

We can imaginatively speak with, rather than for those who cannot speak for themselves, by immersing ourselves in the experiences and stories of those in other cross-cultural settings who have experienced similar marginalization on account of their perceived disabilities. ${ }^{41}$

In the enactments of this man at the pool, I hope to identify a yearning 'for an "elsewhere" -and perhaps, an "elsewhen"-in which disability is understood otherwise as political, as valuable, [and] integral'. ${ }^{42}$

\section{'Bedding Out': Crip-tic Enactments of a Man at the Pool}

In 2012-13, the British artist and disability activist Liz Crow first performed her Bedding Out installation in Salisbury Arts Centre and at the Edinburgh Fringe to campaign against UK welfare cuts for disabilities. The piece involved Liz lying in a bed, exhibiting 'bed life', for 48 hours. By publically exposing and displaying her hidden and protracted experiences of inactivity (bedding out), she

\footnotetext{
35 The event was co-sponsored by the California Arts Council and National Arts and Disability Center at the University of California Los Angeles.

${ }^{36}$ Liz Crow, Arseli Dokumaci, Helen Dowling, Heidi Kayser, Noëmi Lakmaier, Laurence Parent and Sunaura Taylor.

37 See exhibition flyer available online at http://visarts.ucsd.edu/events/performing-crip-time [accessed 10/01/16].

${ }^{38}$ Amanda Cachia, 'Performing Crip Time: Bodies in Deliberate Motion' promotional material online at http://visarts.ucsd.edu/events/performing-crip-time [accessed 10/01/16].

${ }^{39}$ Chandler, Disability, 34-6.

${ }^{40}$ Mark Osteen, 'Autism and representation: a comprehensive introduction', in Mark Osteen (ed.), Autism and Representation (London: Taylor and Francis, 2008), 1-47 (8).

${ }^{41}$ Lawrence, Sense, 5. Original emphasis.

${ }^{42}$ Kafer, Feminist, 3.
} 
hoped to raise awareness of her own, and others' temporalities, and protest against the stigmatizing of disabled bodies as somehow idle, indolent and slothful. She writes:

On this stage, for a period of 48 hours I am performing the other side of my fractured self, my bed life. Since the public me is so carefully constructed, this will be a kind of unperforming of myself. I want to show that what many people see as a contradiction-what they call a fraud-is only the complexity of real life. This is not a work of tragedy, but of in/visibility and complication; a chance to perform myself without a facade. ${ }^{43}$

One of Crow's main purposes was to make explicit the very different 'performances' her disability involved in different spaces, particularly her 'private life as a disabled person' and the presentation of her body at 'its most abject' in marked comparison to 'her public life as an artist' which required presentation of "her impaired self at its most functional. ${ }^{44}$ The performance initiated a number of 'bedside conversations' whereby people were invited to 'gather around the bed to talk about the work, its backdrop and its politics', whilst those unable to attend in person were 'invited to take part virtually, through social media. ${ }^{45}$ In her resulting film and commentary, Bedding In, Bedding Out: Reflections from the Bed, Crow makes clear the cleavages between the public/private and concealed/revealed disabilities that her installation was designed to depict. The bed is a space for both 'preparing for public life and recovering from public life'. It is also a place of revelation: 'some of these people I've known for 10 years and they don't know I'm ill . . that means relationships can't go as deeply as they should. ${ }^{46}$

The story of the man at the pool can also raise awareness of 'bed life' and intentionally juxtapose this against normative rhythms of time and space which include 'recurring feast[s]' which provide 'a cultic rhythm', ${ }^{47}$ and the marking of sacralized time such as Sabbath. The story begins with the narrator stating that Jesus had gone up to Jerusalem as it was 'a festival of the Jews' (v. 1). The scene shifts to Jerusalem's Sheep Gate, ${ }^{48}$ and a pool nearby called $B \eta \theta \zeta \alpha \theta \dot{\alpha}$, which has variously been translated as 'house of mercy' or 'house of outpourings' 49 with five porticoes under which 'lay many invalids-blind, lame, and paralyzed' (v. 3). The focus is directed to a man who had lain there for 38 years. Jesus, knowing his history, directly asks him 'Do you want to be made whole (úpin่s)?' (v. 6). The man replies that he has no one to put him into the pool when the water is stirred up, for when he makes his way down others go in front of him (v. 7). Jesus gives the imperative: 'Rise, take up your mat and walk' (v. 8). The man duly does so. Only at this point are we told it is a Sabbath ( $v$. 9), which forms the context for the remainder of the narrative. The man is approached by 'the Jews' and questioned about his carrying of a mat on the Sabbath (v. 10) and the man reports his encounter at the pool. Jesus meanwhile has 'disappeared into the crowd' (v. 13). Jesus and the man meet later in the temple (v. 14) and Jesus says to him 'See, you have been made whole! Do not sin anymore, so

\footnotetext{
${ }^{43}$ Liz Crow interview, cited online at http://www.bristoldef.org.uk/2013/03/27/bedding-out-created-andperformed-by-liz-crow/ [accessed 10/01/16].

${ }^{44}$ Colin Hambrook provides an overview of Liz Crow's Bedding In, Bedding Out at http://www.creativecase.org.uk/diverse-perspectives-blogs?item=1892 [accessed 10/01/16].

${ }^{45}$ Liz Crow cited in Katie Ellis and Gerard Goggin, 'FCJ-188 Disability's Digital Frictions: Activism, Technology, and Politics', Fibre Culture Journal 26 (2015), available online at http://twentysix.fibreculturejournal.org/fcj188-disabilitys-digital-frictions-activism-technology-and-politics/ [accessed 10/01/16].

${ }^{46}$ Liz Crow, 'Bedding In Bedding Out: Reflections from the Bed' Available online at https://www.youtube.com/watch?v=GUOmDYsOuYl [accessed 10/01/16].

${ }^{47}$ Brodie, Gospel, 26.

${ }^{48}$ On ambiguities surrounding the actual textual variants and renderings of the name of the pool and/or gate, see B. M. Metzger, A Textual Commentary on the Greek New Testament (London: United Bible Societies, 1971), 208.

${ }^{49}$ D. A. Carson, The Gospel According to John (Grand Rapids, MI: Eerdmans, 1991), 241.
} 
that nothing worse happens to you'(v. 14); directly following this, the man returns to the Jews to identify Jesus as the one who commanded him to take up his mat and walk. This prompts the Jews to persecute Jesus for 'doing such things on the Sabbath' (v. 16).

Although John does not specify the exact nature of the man at the pool's condition, commentators have assumed it inhibits his movements, as unaided he cannot enter the pool, and it is chronic given the length of time the man had laid there. He has, however, not only been variously diagnosed as an 'invalid', 'cripple', 'paralytic' or 'lame', but also saddled with associated prejudicial assumptions about his character, including laziness, lethargy, ${ }^{50}$ dullness and naïveté, ${ }^{51}$ which are totally unsupported in the text. Raymond Brown is maddened by the man's temporal sluggishness: 'his crotchety grumbling about the "whippersnappers" who outrace him to the water', which he presumes 'betrays a chronic inability to seize opportunity, a trait reflected in his oblique response to Jesus' offer of a cure. ${ }^{52} \mathrm{R}$. Alan Culpepper also derides the man's claim that his physical inertia is caused by others, and mockingly cites the man's supposition that 'it is their fault that he could not get into the pool when the waters stirred'. ${ }^{53}$ In D. Carson's words, he is nothing but 'an old and not very perceptive man'..$^{54}$

Damaging readings such as these import unwarranted, pejorative and prejudicial assumptions (alien to the text itself) onto the man's body and morality, firmly exiling him among others who lurk precariously on the ideological borders of time and space. The 'confinement' of the man as an outsider, laying for 38 years at the pool (a number some have seen echoing Israel's years in the wilderness, or signifying a whole generation as in Deuteronomy $2: 14,{ }^{55}$ or underlining this man's prolonged 'spiritual impotency'56) could hardly be more pronounced in commentaries. As James Resseguie evocatively reveals, a man such as this 'has no voice in the dominant culture' and is an 'object rather than subject in [his] own right'. His point of view, if ever expressed, 'is marginalized, dragooned by the dominant culture and pilloried as strange' with 'physical ailments that make ... [him] near dead [physically and socially]. ${ }^{157}$ What however would this man's various performances look like when reconceived as a 'bedding out' protest such that the narrative was not casting him as a pitiable or deviant figure, but rather, like Crow's piece, putting the spotlight directly on him to reject the negative assumptions surrounding disabled identities and a providing a provocative revelation of the realities of his day-to-day experience and condition?

What is striking is the ways in which the narrative immediately drills down to concentrate on this man's lived reality, among the many (v. 5). This is also recognised by John Thomas: 'the reader's attention is focused upon one particular man in this mass of people. This technique, not dissimilar to the effect of a zoom lens on a camera, so effectively concentrates the focus of the reader upon this specific person that the rest of the crowd fades from view. ${ }^{58}$ Instead of this being understood as a strategy to underscore his social segregation, ${ }^{59}$ could it be read as a move to emphasize his particular situation and so function as a consciousness-raising cameo for the plight of the countless others around the pool who occupy similar positions (v. 3)?

${ }^{50}$ This no doubt in part reflects the etymological linkage in modern usage of lame, which is 'primarily slang for poor attempt' rather than just 'refer[ring] to human gait'. Gary L Albrecht (ed.), Encyclopedia of Disability (Thousand Oaks, CA: Sage, 2006), 1017.

${ }^{51}$ Carter, 'Blind', 131.

${ }^{52}$ Raymond Brown, The Gospel According to John I-XII (New Haven, CT: Yale University Press, 1966), 209.

${ }^{53}$ R. Alan Culpepper, 'John 5:1-18: a sample of narrative critical commentary', in Mark Stibbe (ed.), The Gospel of John as Literature: An Anthology of Twentieth-Century Perspectives (Leiden: Brill, 1993), 193-207 (204).

${ }^{54}$ Carson, Gospel, 243.

55 Thomas, 'Stop', 7.

${ }^{56}$ Leon Morris, John (Grand Rapids, MI: Eerdmans, 1971), 268.

${ }^{57}$ Resseguie, Strange, 134.

${ }^{58}$ Thomas, 'Stop', 7.

${ }^{59}$ In the words of Resseguie, 'The narrative progressively narrows from a description of the pool to the many sick inside its porticoes to a single man at the pool. . . utterly alone, entombed because of his malady, and in need of a benefactor to reverse his condition.' Resseguie, Strange, 136. 
Similarly, whilst the reference to 38 years could belie an ableist impulse to conceptualize disability temporally-as Kafer notes, 'chronic' fatigue, 'intermittent' symptoms, and 'constant' pain are all ways of 'defining illness and disability in and through time; they define disability in terms of duration' ${ }^{60}$ - the narrative could alternatively be seen to specifically juxtapose the stillness and slow time of the man's condition with active 'normative narratives of times ... definitions of the human in almost all our modes of understanding. ${ }^{\prime 61}$ This is accomplished through references to feasts, holy days and the movement and activities of other characters. It is not coincidental that this is the only occasion within this gospel when we are not told the specifics of the festival that Jesus is attending (v. 1), nor do we know it is the Sabbath until after the encounter at the pool in verse 9. It is almost as if there is a liminal suspension of active time in these verses and, hence in Kafer's words,'rather than bending disabled bodies and minds to meet the clock' this story could be said to exhibit 'crip time bend[ing] the clock to meet disabled bodies and minds. ${ }^{62}$

The narrative also gives the man the opportunity for a bedside conversation with Jesus, in which he directly voices his condition: 'Sir, I have no one to put ( $\beta \alpha \dot{\lambda} \eta)$ me into the pool when the

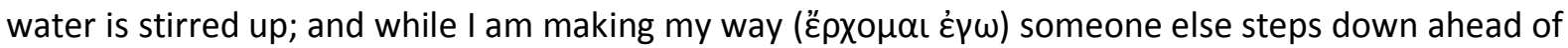

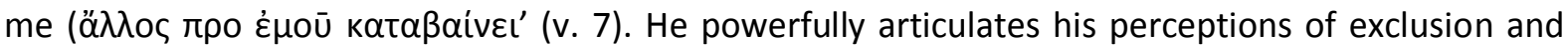
gives voice to the scarcity of aid, resources and help for his condition. Again, temporalities are juxtaposed. Thomas suggests that the word $\beta \dot{\alpha} \lambda \eta$ 'implies the necessity of haste or rapidity of motion. It is impossible to determine why there was such a mad rush to get into the water (first?). ${ }^{163}$ This speed stands in marked contrast to the slow movement of the man.

David Sibley, a cultural geographer, has spoken about the means of 'structuring subjectivity', whereby 'space and society are implicated in the construction of the boundaries of the self but ... . the self is also projected onto society and onto space'. ${ }^{64}$ Space is not an inert or passive container in which life occurs, rather in specific embodied moments 'there is a constant interaction between people and spaces creating and reproducing social space' ${ }^{65}$ Interestingly, as Jay Dolmage has noted,

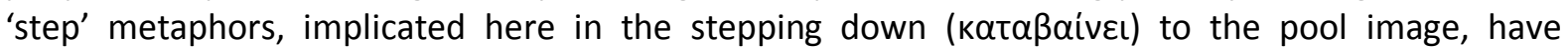
powerful connotations in crip cultures. Interrogating the steps metaphor works to highlight not just how space and spatialization are exclusionary, 'but also the ways that the distance between the hypothetical "us" and the "them", the able and the disabled, [the ill and the cured] has a particular structure' ${ }^{66}$ What is more, his performance also makes clear that his disability is not, as a curative model alone would imply, located only within his body, but rather is evidenced in (or rather in the lack of) a network of relationships. Kafer's work, which is keen to note that disability 'does not occur in isolation', foregrounds and promotes what Robert McRuer has termed the invitation to 'the nondisabled to be crip'. ${ }^{67}$ Crip time is grounded in patient flexibility and is therefore never inherent within one body alone but crystallised within relationships and collaborative enactments. Joshua St. Pierre has similarly demonstrated how crip cultures frequently accentuate both 'spatial politics' and 'the navigation of time' by orientating collaborative activities 'around the axis of the lived body' in all its diversity, rather than with 'objective or clock time' which frequently reflects 'a [singular] dominant able-bodied mode of temporal existence'. ${ }^{68}$ In Jesus' focus on this man's condition and narration of his unknown history (v. 6), the narrative could seem to be involved in an effort to make

\footnotetext{
${ }^{60}$ Kafer, Feminist, 24.

${ }^{61}$ Halberstam quoted in Kafer, Feminist, 34

62 Kafer, Feminist, 27.

63 Thomas, 'Stop', 11.

${ }^{64}$ Sibley quoted in Jay Dolmage, Metis: Disability Rhetoric and Available Means, Ph.D. thesis, Miami University (2006), 86. Available online at https://etd.ohiolink.edu/rws etd/document/get/miami1154379257/inline [accessed 10/01/16].

65 Sallie Westwood, Power and the Social (London: Routledge, 2002), 91.

66 Dolmage, Metis, 155.

${ }^{67}$ McRuer, cited and discussed by Kafer, Feminist, 13.

68 Joshua St. Pierre 'Distending Straight-Masculine Time: A Phenomenology of the Disabled Speaking Body', Hypatia 30, 1 (2015), 49-65 (50).
} 
his disability present for all to see and, at least in that bedside moment, to construct a suspension of ableist ideals of time and space in order to show how inter-relationships are vital to crip enactments.

The intersectional marginalities (physical, social and economic) of the man are also brought into sharper relief when set alongside Crow's protest. Underscoring this man's social position, Brown

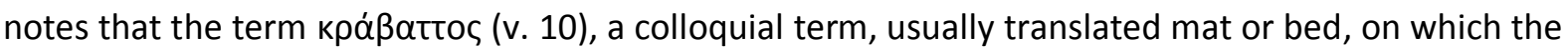
man lies, was frequently used for the pallet, mattress, or bedding of the poor. ${ }^{69}$ Rather than the 'weak grumblings' of a lazy man, this could be reconceived as a consciousness-raising 'bedding out' of the economic lot of those others blind, lame and withered/paralyzed, who are sheltering under the covered porticoes of the gate. Christian Laes' work on disability in the Roman world across different social strata makes important points in this regard. He notes how, in elite written sources, mobility problems 'need not be limiting at all': 'the wealthy were supported or even carried by servants and slaves'. This was in direct contrast to the serious disablement that mobility issues could pose for those at the lower end of the scale, who would be rendered unfit for most work and activity in their communities:

Hence one encounters in one and the same society the heroification of a physically impaired king and the admiration of war veterans, but also .... despise for the very same ... [those] who were considered deformed or disfigured. ${ }^{70}$

This man's bedding out, like Liz Crow's, could be perceived then as a sort of 'unperformance'; where a private self is made visible and the stillness of his lived body explicitly articulated. Moreover, in this enactment between the man and Jesus, a 'human story' is put into 'a broader [physical, social and] political context'. ${ }^{71}$ Time, space and embodiment are, at least at that moment as the man lays on a pauper's bed, powerfully displayed and suspended(/cripped?).

\section{'One Morning in May': Crip-tic Enactments of a Man at the Pool}

On 28 May 2012, Noëmi Lakmaier, a disabled performance artist, clad in business dress, made the journey from Toynbee studios in Tower Hamlets, the East End of London, to the Gherkin building, 'one of the most iconic pieces of architecture and a symbol of London's place within the global financial industry'. ${ }^{72}$ For 'normate' bodies, the 'walk' would take around one and half hours; for Lakmaier, however, it took seven hours, as she moved and crawled on her hands and knees. Her 'professional' attire got increasingly stained and tattered as her journey progressed. Lakmeier describes her piece as a purposeful 'role-play with the viewer who is forced into the dominant role through my action, forced to react in one way or another'. ${ }^{73}$ Accordingly, she elicited a number of responses from passers-by, from inquisitive stares, to direct questions asking whether she needed help or what she was doing. She used these encounters as opportunities to raise awareness about intersecting marginalities. In her words:

\footnotetext{
69 Jodi Magness, 'Sweet memory: archaeological evidence of Jesus in Jerusalem', in Karl Galinsky (ed.), Memory in Ancient Rome and Early Christianity (Oxford University Press, 2015), 324-43 (328).

${ }^{70}$ Christian Laes, Chris Goodey and M. Lynn Rose, 'Disabilities in Roman Antiquity: disparate bodies A Capite ad Calcem', in Christian Laes, Chris Goodey and M. Lynn Rose (eds), Disabilities in Roman Antiquity: Disparate Bodies A Capite ad Calcem (Leiden: Brill, 2013), 1-16 (8).

${ }^{71} \mathrm{Liz}$ Crow, cited and available online at http://beddingout.roaring-girl.co.uk/reminding-myself-why-by-lizcrow-beddingout [accessed 20/01/16].

${ }^{72}$ See https://www2.le.ac.uk/hosted/attenborougharts/documents/pdfs/art-life-activism-exhibition-guide [accessed 20/01/16].

73 Lakmaier, cited and discussed in Colin Hambrook, 'Disability arts', in Colin Cameron (ed.), Disability Studies:

A Student's Guide (Thousand Oaks, CA: Sage, 2013), 30-2 (31).
} 
I wanted to cross over the border of these worlds ([the] poverty of Tower Hamlets versus [the] affluence of City of London) in a slow and strenuous way, dressed as them while clearly being Other socially, politically, economically and physically. ${ }^{74}$

Lakmeier's One Morning in May performance was designed to demonstrate how far out of reach not only 'the city' (physically, ideologically and socially) is for the disabled, but also it sought to underline the gap between rich and poor and critically comment on 'the symbiotic relationship between disablement and capitalism'. ${ }^{75}$

The story of the 'man at the pool' could, I suggest, similarly be read as remonstrating against spatial and ideological segregations, this time based on sacred time and space respectively represented in this story by Sabbath and temple. The narrative is commonly referred to either as 'The Healing at the Pool' or 'A Sabbath Healing'.$^{76}$ The former points to a presumed curative miracle, whereas the latter implies the transgression of religious maps of time. Many commentators have focussed on the latter, though typically their energies are directed to Jesus' words and attitudes rather than to the actions of the man at the pool, who is understood merely to follow instructions given to him. As Kevin Quast notes, 'Jesus presents himself as the Son of God who has the authority to work on the Sabbath'. ${ }^{77}$ Others have argued that here is a healing tradition which may have been purposefully redacted by John into a Sabbath controversy to speak to rising tensions in his own era between his community and the synagogue; again though the focus and rationale for such interpretations is largely Christological. In Gail Yee's words:

By transforming the traditions into a Sabbath controversy, John is able, on the one hand, to articulate Jesus' mysterious relationship to the Father, a theological affirmation that was bound to alienate the Jewish community. On the other hand, John is able to develop two related Christological themes through his Sabbath dispute: Jesus as the one who gives life and Jesus as the one who judges. ${ }^{78}$

However, drawing inspiration from Lakmaier, what if the transgression of time (and space) is centred on the actions of the man himself, most particularly the movement of his non-normative body from spaces of exclusion into centres of power? Mikeal Parsons' important work on 'physiognomic consciousness' in the gospels is instructive in this regard. ${ }^{79}$ Physiognomic conventions- 'judgments about moral character ... made from an examination of the physique and its aspects ${ }^{80}$ - prevalent in ancient rhetoric, play a part in this story's othering of a non-normative body. ${ }^{81}$ Parsons reveals how disabilities of the legs, feet and ankles were frequently associated with feebleness, effeminacy and cowardice. Read in this light, could Jesus' imperative to 'Rise (Egeire) up, take your mat and walk' ( $v$. 8) be seen to provoke not a physical 'cure' of a biomedical disease, but rather a social 'healing' of the stigma surrounding the illness; to purposefully employ a modern phrase: a 'rising up' for one's rights, and a movement from exclusion to inclusion? For although most modern translations render Jesus' imperative command with a physical translation: Stand up! (v. 8), Egeire can variously be translated as 'raise up', 'stir up', 'bring into being' or 'rise up in arms'. The root is used elsewhere in John not only to denote the raising up of the temple $(2: 20,22)$ and raising of the

\footnotetext{
${ }^{74}$ Hambrook, 'Disability', 31.

${ }^{75}$ Art, Life, Activism Exhibition Guide, University of Leicester, Available online at https://www2.le.ac.uk/hosted/attenborougharts/documents/pdfs/art-life-activism-exhibition-guide [accessed 20/01/16].

${ }^{76}$ O'Day and Hylen, John, 63.

${ }^{77}$ Kevin Quast, Reading the Gospel of John: An Introduction (New York: Paulist, 1991), 40.

78 Gale A. Yee, Jewish Feasts and the Gospel of John (Eugene, OR: Wipf \& Stock, 1989), 41.

79 Mikeal Parsons, 'The Lame Man in Acts 3-4', Journal of Biblical Literature 124 (2005), 295-312.

${ }^{80}$ Pamela Shellberg, Cleansed Lepers, Cleansed Hearts: Purity and Healing in Luke-Acts (Minneapolis, MN:

Fortress, 2015), 53.

${ }^{81}$ See Carter, 'Blind', 130.
} 
dead (12:1) but also the purposeful 'raising up' to purposeful action (14:31). ${ }^{82}$ Could therefore the command be read as a provocative invitation to display his disability rather than a demand for curing it?

Nancy Mairs, a wheelchair user, who unveils the ways in which 'healthy,' normal and 'proportional' bodies construct morality aligned with physical form, makes instructive reading in this regard. She contrasts the metaphors of being morally 'upstanding' with negatively 'being looked down upon' ${ }^{83}$ As such 'the body that shaped the language is not hers-in fact, the language negates her body'. ${ }^{84}$ Jay Dolmage suggests therefore that 'part of the rhetorical work that needs to be done is to stroll subversively' ${ }^{85}$ In articulating such a 'subversive strolling' here, the distinction between 'curing' (physical/biomedical normalization) and 'healing' (social integration and overcoming of stigma associated with conditions), which both John Dominic Crossan and John Pilch have been keen to draw in relation to Jesus' healing ministry, ${ }^{86}$ is insightful. In these sorts of alternative readings, the man may not be physically healed, but does experience social healing and is encouraged to move from his 38 year exclusion from the temple (see Lev. 21:17; 2 Sam. 5:8) into temple space (v. 14). It is perhaps not insignificant then, 'that Jesus does not ask the man whether he desired to be healed, but rather whether her desires to be whole'.$^{87}$

Just as Lakmaier purposefully moves from spaces of poverty to centres of financial power as a territorial claim that non-normative bodies are excluded from such places, so Jesus' imperative

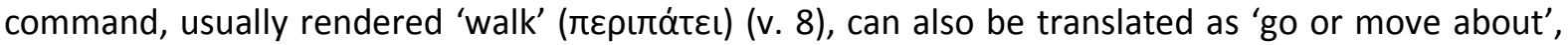
'live' or 'conduct oneself'. Rather than assuming a physical walking, what if this action is conceived as an alternative physical movement (a subversive stroll?) and a change of perspective regarding one's identity? We can assume the man 'moves' (albeit slowly) as earlier in the narrative he speaks

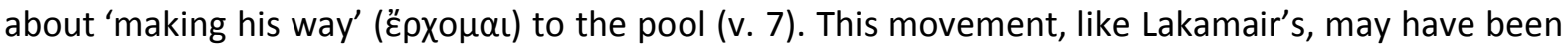
more of a 'crawl'. Diane DeVries, a 'congenital amputee' 88 born without arms or legs, underscores how naive those with able limbs can be about the process of 'walking' and movement. She was ambulatory by swinging her 'hips back and forth' and could also stand on her head. She notes how they (the medical profession) 'discovered I had hips and that surprised me, because I figured that if I'm walking, of course I had them.' ${ }^{89}$

Lending weight to this admittedly unusual reading is the fact that the Jews seem totally unaware a healing has taken place (v. 10); rather they chastise the man for his action of carrying his

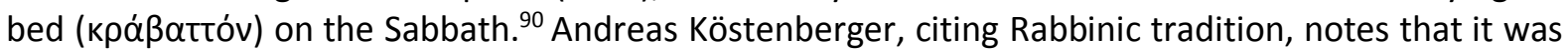
permissible to 'carry a bed with a person lying on it, but not one that was empty'91 (cf. m. Šab. 11.111). Could the force of the man's action then be not only carrying an object (the pauper's mat) from one socio-economic domain into another, but also displaying and moving his 'disabled' body (which Levitical law would seek to exclude, see Lev 21:17-21) into the sacred courts of the temple? Jesus' later encounter with the man in the temple, where he addresses him with the words 'See ("$\left.{ }^{\prime} \delta \varepsilon\right)$ you have been made whole. Do not sin anymore' (v. 14) in this vein is not an acknowledgment of the link

\footnotetext{
82 Of course many words have a range of meanings and context determines which is most plausible, but the refiguring/cripping of dominant modes of translation/interpretation necessarily involves transgressive alternatives, which at the very least, question presumed monolithic meanings.

${ }^{83}$ Nancy Mairs, discussed and cited in Dolmage, Metis, 121.

84 Dolmage, Metis, 121.

85 Dolmage, Metis, 121. My italics.

86 John Dominic Crossan, The Historical Jesus: The Life of a Mediterranean Jewish Peasant (London: Harper Collins, 1992), 336-7; John Pilch, Healing in the New Testament: Insights from Medical and Mediterranean Anthropology (Minneapolis, MN: Fortress, 2000), 19-38.

87 Thomas, 'Stop', 9-10. My italics.

${ }^{88}$ Geyla Frank, 'On embodiment: a case of congenital limb deficiency in American culture', in Michelle Fine and Adrienne Asch (eds), Women with Disabilities (Philadelphia, PA: Temple University Press, 1988), 41-71 (49).

${ }^{89}$ Frank, 'Embodiment', 51.

90 Köstenberger notes that this is 'an instance of Johannine irony'. Köstenberger, John, 181.

${ }^{91}$ Köstenberger, John, 181.
} 
between sin and illness, but rather a testimonial to this man's courage in subversively contravening maps of exclusion. As O'Day and Hyden likewise submit: 'A better way of reading these words may be that Jesus now urges the man to live his life in a way that reflects his "having been made well"'. ${ }^{92}$ Thomas lends weight to this when he notes that in other instances within the gospel where $1 \delta \varepsilon$ is used, it is 'so as to reveal something about his or her situation, mission, or destiny (cf. 1:19-34; 1:359; $1: 47-51 ; 19: 24-7)$ ', thus perhaps this 'formula is used [here] intentionally to draw attention to the nature of his wholeness. ${ }^{93}$

In this hypothesized criptic enactment, the man at the pool defiantly leaves his marginal space, and purposefully displays his disability to move slowly, but subversively to the temple to stake his place within it. In Resseguie's estimation, he is freed 'from the constraints of the dominant culture that regarded him as nothing more than a waif in the first place'. ${ }^{94}$ 'He is active, even becoming an avatar of a Sabbath-violator. ${ }^{95}$

These sorts of insights challenge the dominant temporality of 'curative time' often assumed within Johannine scholarship on the 'healing' signs. This designates the way in which futures of disability always require 'intervention', often elimination and/or normalization/cure of those bodies which are perceived not to live, act, develop or work according to dominant, ableist patterns. Pauline A. Otieno makes a similar point in reference to biblical interpretation and the marginalization of persons with disability in Kenya. She submits that 'healing [as opposed to curing] means creating environments in which people with disabilities can participate fully in society' and cites the following story to illustrate her point:

Clutching his ragged clothes around him, Kamau traced his steps slowly and steadily through the corridor to the main entrance of the church. It was Christmas day and the pews were overflowing with people. As the congregation stood up to sing, Kamau made his way through the celebrants. Suddenly, a rough hand gripped him and dragged him out. 'I have not come to beg,' he said. 'I want to worship the Lord.' Before long, he was thrust outside the gate. Remorse and shame filled his heart and choked his voice. He sat down slowly cupping his head in his hands. 'Why, oh Lord, Why am I blind?' he fumed within. 'Isn't it just because I am blind, that I wasn't allowed to stay in?' 'Don't I also have a soul?'96

Kafer specifically contrasts 'curative time' with 'crip time' marked by fissures of ableist temporalities ${ }^{97}$ and a figuring of 'what it means to project disability into the future'. ${ }^{98}$ In her words, 'the task . . . is not so much to refuse the future as to imagine disability and disability futures otherwise, as part of other, alternate temporalities that do not cast disabled people out of time, as the sign of the future of no future'. ${ }^{99}$ She notes how time and space (both metaphorical and material) in crip culture 'get[s] imagined differently' for purposes of 'creating accessible futures'. In McRuer's words, criptic enactments 'expose ways in which bodies, minds, and impairments that should be at the absolute centre of a space or issue or discussion get "purged" from that space or issue or discussion'. ${ }^{100}$ Spaces, in the words of Katherine McKittrick, 'normalize and calibrate where, and therefore who, we are'. ${ }^{101}$ Consequently criptic interventions of the sort proposed here

\footnotetext{
92 O'Day and Hylen, John, 65.

93 Thomas, 'Stop', 15.

${ }^{94}$ Resseguie, Strange, 137.

95 Resseguie, Strange, 137.

${ }^{96}$ Pauline A. Otieno, 'Biblical and Theological Perspectives on Disability: Implications on the Rights of Persons with Disability in Kenya'. Available online at http://dsq-sds.org/article/view/988/1164 [accessed 20/01/16].

97 Kafer, Feminist, 21.

98 Kafer, Feminist, 20.

99 Kafer, Feminist, 34.

100 McCruer, Crip, 2014.

101 Katherine McKittrick, Demonic Grounds: Black Women and Cartographies of Struggle (Minneapolis: University of Minnesota Press, 2006), xi.
} 
powerfully disrupt, challenge and rearticulate the ways in which we comprehend the bodies which inhabit or are controlled by certain spaces. Karen Bray makes interesting points in this regard. She contends that to 'embrace the stigma of sickness is to question the demands of [neo-liberal] productive labor on offer by a society.' Rather than configuring healing stories in the gospels as a reintegration into productivity, she probes what potentials there are within 'unproductivity' to 'counter neo-liberal constructions of value'? Adopting crip theory, she unsettles a tradition which equates productivity with redemption. Thus in reference to the man at the pool, in Bray's words:

Instead of asserting that our faith traditions have been built on action, and honouring the demand that the 'invalid' in John stand up, take his mat and walk, to locate the potency of the multitude in its unproductivity is to ask why the man was sitting in the first place and for whom and what he would be walking. ${ }^{102}$

Such understandings (in challenging a curative imaginary) also underscore the belief that 'illness is more than just the absence of health, because healing is more than simple restoration of physical well-being'. ${ }^{103}$

\section{Vital (Johannine) Signs: Crip-tic Enactments of a Man at a Pool}

The anthropologist Nigel Rapport, in the introduction to his volume Human Nature as Capacity: Transcending Discourse and Classification (2010), submits that anthropology should 'apprehend the human as a complex singularity, not on the basis of substance (to be human is to be like this, to want this, to have this) but in terms of capacities: capabilities for action and imagination'. ${ }^{104} \mathrm{He}$ is aware that 'human nature' as a concept has been compromised by 'essentialistic, hierarchical and exclusionary histories' which have played a part in sustaining the 'imperialism of male over female, adult over child, advanced over primitive, Occidental over Oriental, rational over emotional, conscientious over brutish, [and able over disabled] as representative of the essentially human'. ${ }^{105}$ In his opinion, by reframing human nature in terms of capacities anthropological attention is turned to particular 'action[s] and the ethnographic: to activities witnessed in the field and intuiting of their causes and meanings.'106 Through such means he submits, 'an appreciation of the richness, the ambiguity, complexity and flux of experience ... [and the] irreducible variety [of human action] ${ }^{107}$ can be revealed.

The crip-tic enactments of the man at the pool proposed here-an embodiment of slow time, a protest against socio-economic injustice and spatial discrimination based on bodily difference and a purposeful display of one's disability rather than a curing normalization-have sought to employ a similar strategy. Rather than seeing this character as 'linger[ing] on the border[s] between death and cure-the only two acceptable states' ${ }^{108}$ for non-normative bodies, I have sought, through the purposeful juxtaposition of his story with two contemporary crip performance pieces, to encourage him to subversively 'talk back' at his dominant (ableist) interpretative histories. Whilst it is largely true that 'the strangely formed body has represented absolute Otherness in all

\footnotetext{
102 Karen Bray, 'The Monstrosity of the Multitude: Unredeeming Radical Theology', Palgrave Communications 1 (2015). Available online at http://www.palgrave-journals.com/articles/palcomms201530 [accessed 01/03/16]. 103 Bert Jan Lietaert Peerbolte and Michael Labahn, Wonders Never Cease: The Purpose of Narrating Miracle Stories in the New Testament and its Religious Environment (London: T\&T Clark, 2006), 124.

104 Nigel Rapport, 'Human nature as an exceeding, a going beyond', in Nigel Rapport (ed.), Human Nature as Capacity: Transcending Discourse and Classification (New York: Berghahn, 2010), 1-28 (2).

105 Rapport, 'Human', 1.

106 Rapport, 'Human', 2.

107 Rapport, 'Human', 14.

${ }^{108}$ Anne Finger, Call Me Ahab: A Short Story Collection (Lincoln: University of Nebraska Press, 2009), 4.
} 
times and places since human history began', ${ }^{109}$ biblical scholarship, in perpetuating this assumption, has prejudicially imported pejorative understandings of this character into their interpretations. The hermeneutical experiment initiated here, in alignment with postcolonial methodologies, tries to evoke alternative voices muted through dominant transcripts. Commenting on such strategies, Musa Dube and Jeffrey Staley state:

The journey we [biblical scholars] choose to participate in, and the space we inhabit our reading practices are, therefore, acts that have an impact on our worlds and our neighbour's worlds. ... And we, as readers, cannot be neutral in this struggle. ${ }^{110}$

By probing, albeit in highly experimental ways, alternative readings of this character's lived body's various performances, and defying what Kafer has termed the 'curative imaginary', ${ }^{111}$ an alternative 'crip' spatio-temporal framework has been proposed. In this temporality, as Dawn DeVries notes: 'new creation [is] understood not in terms of restoration of the old order but as a fashioning of a new order in which pain [is an] inducement to a new understanding of community. ${ }^{112}$

The man at the pool, like Crow and Lakmaier in their respective performances, 'aligns crip time' and exhibits 'a kairotic strategy occasioned by [his] disability'. ${ }^{113} \mathrm{He}$ demonstrates against social, political, religious and economic forces which exclude or mark his body with solely a negative ontology. His enactments showcase moments in which 'actors, activities and situations [are] involved in the unstructured, unexpected, spontaneous interactions that socially produce or do crip. .. [where] the meaning of disability is enacted differently . . communally, and not necessarily as a problem'. ${ }^{114}$ Such interpretations of course challenge the theological, spiritual and other-worldly meanings often accorded to this, and other healing 'signs', within John's gospel. Yet, whilst as Jennifer Berensen Maclean recently noted, 'Jesus' role as shaper of culture-[time and space] specifically of the Johannine community-needs little elaboration', ${ }^{115}$ the sorts of crip-tic enactments suggested here also move towards disabled bodies themselves, not being mere props in 'curative narratives' but central and constitutive of gospel worlds, time, space and communities. As Nancy Eiesland submits, 'the body's multiple parts and differentiation, complex interactive systems, boundaries, and senses serve as metaphors for the organization of social space. Thus, as we expand our idea of what makes up a representable body, we expand our idea of how to arrange space itself'. ${ }^{116}$

Vital Signs, the celebrated crip video-documentary with which I introduced this piece, was specifically titled as a resistant play on biomedical 'vital signs' of life (pulse, blood pressure, temperature, respiration rates, etc.), and instead designed to exhibit and affirm a far richer experience of 'lived bodies'. In Mitchell and Synder's words:

\footnotetext{
109 Leslie Fiedler, 'Foreword', in Rosemary Garland Thomson (ed.), Freakery: Cultural Spectacles of the Extraordinary Body (New York University Press, 1996), xiii-xviii (xiii).

${ }^{110}$ Musa Dube and Jeffrey Staley, 'Descending from and ascending into heaven: a postcolonial analysis of travel, space and power in John', in Musa W. Dube and Jeffrey Staley (eds), John and Postcolonialism: Travel, Space, and Power (Sheffield Academic Press, 2002), 1-10 (10).

${ }^{111}$ Kafer, Feminist, 27.

112 Dawn DeVries, 'Creation, handicappism and the community of differing abilities', in Rebecca Chop and Mark Taylor (eds), Reconstructing Christian Theology (Minneapolis, MN: Fortress, 1994), 137.

${ }^{113}$ Shannon Walters, Rhetorical Touch: Disability, Identification, Haptics (Columbia: University of South Carolina Press, 2014). No page numbers.

${ }^{114}$ Chandler, Disability, 30-1.

115 Jennifer Berenson Maclean, 'The divine trickster: a tale of two weddings', in Amy-Jill Levine and Marianne Blickenstaff (eds), A Feminist Companion to John (Sheffield Academic Press, 2003), 48-77 (72).

${ }^{116}$ Carrie Sandahl, 'Considering Disability: Disability Phenomenology's Role in Revolutionizing Theatrical Space', Journal of Dramatic Theory and Criticism 16 (2002), 17-32 (24-5).
} 
We sought to make our own subjects larger-than-life. While people with disabilities usually find themselves equated with contagion, undesirability, wasting innocence, or tragedy, our video evokes an intimacy with its interviewees and performers. In this sense, Vital Signs embodies a visual revolutionary praxis: get the faces of our community on screen... rather than assume a false repugnance or artificial distance. ${ }^{117}$

The cript-tic enactments of the man at the pool, whom Alan Culpepper once declared to be 'the most enigmatic character ${ }^{118}$ of the fourth gospel, constitute a similar refiguring of (vital) Johannine signs. His performance poses a provocative challenge to those interpretations which would shrink his character 'into insignificance', ${ }^{119}$ and instead seeks to recover his (and all bodies') creative capabilities, agencies, complexities and (dis)abilities. ${ }^{120}$

${ }^{117}$ David Mitchell and Sharon Snyder, 'Talking About Talking Back: Afterthoughts on the Making of the Disability Documentary Vital Signs: Crip Culture Talks Back', Disability, Art, and Culture 37, 2 (1998). Available online at http://hdl.handle.net/2027/spo.act2080.0037.216 [accessed 20/01/16].

${ }_{118}$ R. Alan Culpepper, The Gospel and Letters of John: Interpreting Biblical Texts Series (Nashville, TN: Abingdon, 1998), 150.

${ }^{119}$ Douglas Ellory Pett, The Healing Tradition of the New Testament (Cambridge: Lutterworth, 2015), 106.

${ }^{120}$ I am deeply grateful to my colleagues Prof David Horrell and Dr Susannah Cornwall for reading and commenting on drafts of this piece. 